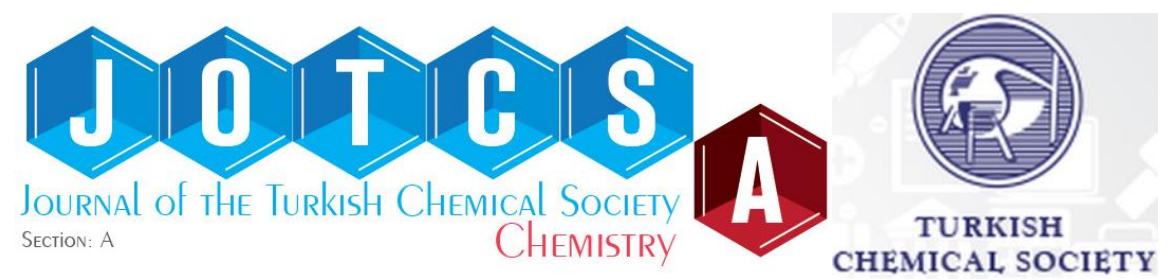

\title{
Gross Alpha and Gross Beta Activity Concentrations in Sediments in Gulf of Izmir (Eastern Aegean Sea, Turkey)
}

\author{
Erol Kam ${ }^{1, * D}$, Zeki Ü. Yümün² ${ }^{-1}$, Dilek Kurt ${ }^{1}$ (D) \\ 1. Yildiz Technical University, Faculty of Arts and Sciences, Physics Department, \\ Davutpasa Campus, 34220 Esenler/ İstanbul, TURKEY \\ 2. Namık Kemal University, Çorlu Engineering Faculty, Environmental Engineering \\ Department, 59860 Çorlu, Tekirdağ, TURKEY ${ }^{1}$
}

\begin{abstract}
The concentrations of gross alpha and gross beta radioactivity were analyzed in Holocene sediments of the Gulf of Izmir (Eastern Aegean Sea). The sediments were collected from four different locations affected by industrial activities, overpopulation, and shipping in the Gulf of İzmir. Each sample was determined for gross alpha and gross beta radioactivity by using a low-background counter (Berthold, LB 77010 - channel $\alpha-\beta$ low-level counter). The obtained results show that natural gross alpha and gross beta activity concentrations in the drilling cores range from $537 \pm 77$ to $1800 \pm 207 \mathrm{~Bq} \mathrm{~kg}^{-1}$ and $993 \pm 60$ to $1842 \pm 102 \mathrm{~Bq} \mathrm{~kg}^{-1}$, respectively. These results were compared with previous studies throughout the world, and the study could be a reference data for the future researches related to radiological mapping or environmental monitoring in the area.
\end{abstract}

Keywords: Gross alpha, gross beta, Gulf of Izmir, sediment.

Submitted: February 10, 2017. Accepted: August 22, 2017.

Cite this: Kam E, Yümün Z, Kurt D. Gross Alpha and Gross Beta Activity Concentrations in Sediments in Gulf of Izmir (Eastern Aegean Sea, Turkey). JOTCSA. 2017;4(3):889-98.

DOI: $10.18596 /$ jotcsa. 291318.

*Corresponding author. E-mail: erolkam@yildiz.edu.tr.

${ }^{1}$ zyumun@nku.edu.tr. 


\section{INTRODUCTION}

Natural background sources of radiation are divided into cosmic radiation, primordial radiation, and cosmogenic radioactivity (1). Cosmic radiation is the earliest source, which emerges at the formation of the universe. Primordial radionuclides are the second source that created with the occurrence of the Earth, and its essential radionuclides are U-238, Th-232 and their decay products, besides natural $\mathrm{K}-40$ (2). The third source of natural background radiation is cosmogenic radioactivity that is formed as a result of interactions between cosmic radiation and the atmosphere in a continuous manner. The mainly cosmogenic radionuclides are ${ }^{3} \mathrm{H}$ (tritium), ${ }^{7} \mathrm{Be}$ (beryllium-7) and ${ }^{14} \mathrm{C}$ (carbon-14) (3). Additionally, artificial radionuclides such as Cs-137, Cs-134, Sr-90, and I-131 are generated by a number of human activities. (4). Most of the radioactive elements in the marine environment mainly come from atmospheric nuclear weapons testing, nuclear reactor accidents, and non-nuclear industries $(3,5)$.

The measurement of radioactivity is crucial to evaluate the radiation effect on the environment and living organisms. Radioactivity is a form of energy released from radioactive elements, and the degree of damage depends on many factors such as dose rate and type of radiation (alpha, beta, gamma, $x$-ray, and neutron radiation). The easiest way to detect for the total radioactivity in the samples is the detection system. (6).

Alpha particles are being made up of two protons and two neutrons; therefore, they have a positive electrical charge. Alpha emitting radiation comes from naturally occurring elements such as uranium and radium and some man-made elements. Because of their charge and relatively large size, alpha particles collide strongly with matter and drop their energy quickly. They are unable to penetrate the first layer of skin, but if an alpha emitting material is ingested in food or air, they can affect the body cells.

Beta particles are fast moving electrons or positrons ejected from an atom. They are much smaller than alpha particles and can penetrate a few centimeters of skin or water. A thin sheet of aluminum or plastic can stop them.

Sediments have a crucial role in the aquatic environment as they accumulate and distribute radioactive contaminants in the geographic areas. Gross alpha and gross beta activity concentrations in sediments are defined as the total radioactivity of all alpha and beta emitters. Gross alpha radioactivity comes from U-238, Th-232, Ra-226, Rn-222 and their decay products, while gross beta radioactivity consists of naturally long-lived K-40, and fission products of Sr90, Cs-137 and I-125 (7). Consequently, analyzing sediment samples in marine medium enables valuable information with regard to environmental pollution including natural and artificial radioactivity (2). 
Gross alpha and gross beta analysis are generally carried out as a screening measurement for determining alpha and beta radioactivity in environmental research (4). This study presents the analysis of gross alpha and gross beta activity concentrations of sediment specimens in the Gulf of Izmir.

\section{EXPERIMENTAL}

\section{Study Area}

The Gulf of Izmir is a semi-open natural gulf, and located in the Eastern Aegean Sea (Figure 1). It has a total surface area of over $500 \mathrm{~km}^{2}$, a total length of $64 \mathrm{~km}$, and water capacity is 11,5 billion $\mathrm{m}^{3}(8)$. The Gulf is naturally divided into three regions: Inner, Middle and Outer in terms of topographic and hydrographic circumstances (9). Important streams and rivers flow into the Gulf of Izmir are Bostanlı, Ilıca, Bayraklı, Bornova, Manda, Arap, Melez, Poligon, Balçova, Narlıdere and Gediz River that is the biggest one flows to the outer Gulf (10). The Outer Section is situated from Karaburun to Foca with distance $20 \mathrm{~km}$. The depth reaches up to $70 \mathrm{~m}$ in the outer Gulf while swallowing towards to the inner Gulf ( $\max 15 \mathrm{~m}$ ). The middle and inner Gulf in total have $36 \mathrm{~km}$ long and $6-8 \mathrm{~km}$ wide. The major sources of pollution flow to the Gulf are streams and over hundreds of small domestic discharges.

The industry in Izmir is densely populated in comparison to the middle and the outer Gulf. The major sources of income are food, oil, tannery, chemical industry, soap, paint production, paper and pulp mills, wood processing, cement factory, metal processing and beverage bottling factory (9).

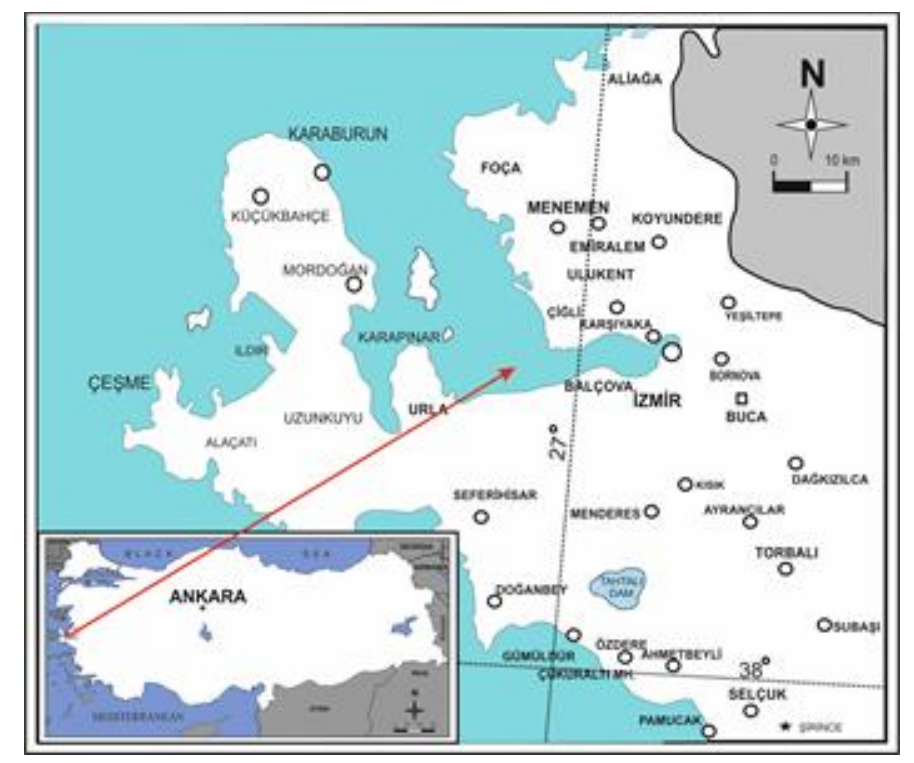

Figure 1: Location map for the study areas. 


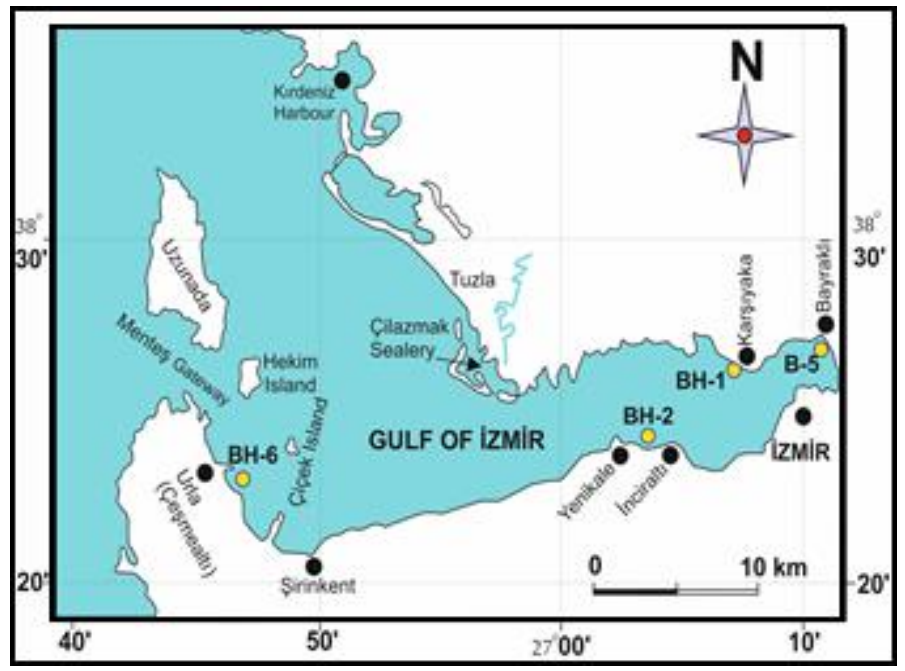

Figure 2: Location map of four sampling stations.

\section{Sampling and Preparation}

The young sediment drill hole samples were collected from the 4 stations in the Gulf of Izmir $\left(38^{\circ} 41^{\prime}-38^{\circ} 21^{\prime} \mathrm{N}, 26^{\circ} 30^{\prime}-27^{\circ} 08^{\prime} \mathrm{E}\right.$ ) as a part of a drilling platform of the YUMUN01 in 2013 (Figure 2). The points of the core drilling method were selected by considering paleontological and sedimentological features. Investigated areas are Karsiyaka $\mathrm{BH}-1$, Bayrakli $\mathrm{BH}-5$, Inciralti $\mathrm{BH}-2$ and Cesmealti $\mathrm{BH}-6$, and the depths of core sediment samples change between 0 to 30 meters (Table 1). In a vertical distribution of the drilling sediment samples have different components (Table 2). The components of the sediments in Karsiyaka $\mathrm{BH}-1$ and Bayrakli BH-5 are blackish gray sandy clay with high water content (slime), Inciralti BH-2 is less sandy, greenish gray colored clay (slime), and Cesmealti BH-6 is blackish gray colored sandy shelled clay with high water content (slime).

The core samples were collected in the form of the $1.5 \mathrm{~m}$ maneuvers and lined up in core boxes. At the end of the sounding, the sediment samples placed in a plastic bag immediately and brought to the laboratory. The samples were kept at room temperature for one week and prepared for radioactivity analysis.

The bottom sediments of the Gulf of Izmir are affected by the meteorological activities, waves, topographic characteristics of the land, and morphological properties of the undersea (11). The Gulf's sediment grain sizes turn into minor as it goes from the coast to deeper sea levels (12).

\section{Experimental Setup}

The activity concentrations of the gross alpha and beta in the core sediment samples were measured using a gas proportional $\alpha / \beta$ counter of low background multiple detector type (Berthold LB-770). The dried sediments were ground and then powdered before analyzing. Approximately $130 \mathrm{mg}$ of each powder were weighed on a sensitive balance and transferred into the empty planchet. Distilled water was dropped homogeneously and spread the sediments on 
the planchet.

Table 1: Properties of the drilling samples (13).

\begin{tabular}{|c|c|c|c|c|}
\hline Sample No & $\begin{array}{c}\text { Depth of Sample } \\
(\mathbf{m})\end{array}$ & Quantity of Sample (g) & \multicolumn{2}{|c|}{$\begin{array}{c}\text { Sample Coordinates } \\
\text { (WGS-84, 6 } \mathbf{~}^{\mathbf{}}\end{array}$} \\
\cline { 3 - 5 } & & & $\mathbf{X}$ & $\mathbf{Y}$ \\
\hline Karşıyaka $\mathrm{BH}-1$ & $12,50-13,50$ & 1047 & 4255697 & 510456 \\
\hline Bayraklı BH-5 & $6,50-7,50$ & 1021 & 4258790 & 513920 \\
\hline İnciraltı $\mathrm{BH}-2$ & $10,00-12,00$ & 1023,5 & 4253810 & 502590 \\
\hline Çesmealtı $\mathrm{BH}-6$ & $4,50-5,00$ & 1035,7 & 4249770 & 478170 \\
\hline
\end{tabular}

Each sediment sample was dried in an oven at $105^{\circ} \mathrm{C}$ for 2 hours. The sediments were kept in a desiccator to return to room temperature without moisture. After these procedures, $100 \mathrm{mg}$ of the each sediment were taken, again weighed on a sensitive balance, and dried in an oven at $105{ }^{\circ} \mathrm{C}$ for 2 hours. They were kept in a desiccator repeatedly.

Finally, all sediments were counted for 1000 min in 2 cycles by LLB 770 system to obtain gross alpha and gross beta activity concentrations. The system was calibrated for gross alpha and gross beta radioactivity by using the same concentration standard and known sample geometries of Am-231 and Sr-90 solutions (14).

Activities were calculated by using equations below:

$$
\begin{gathered}
\text { Activity }(\quad)=\frac{\text { NetCounting }}{60 \quad \text { Efficiency Mass }(\mathrm{kg})} \\
\text { Activity( ) }=\frac{N(\quad) \quad B(\text { crosstalk })}{60 \quad \text { Efficiency Mass }(\mathrm{kg})}
\end{gathered}
$$

\section{RESULTS AND DISCUSSIONS}

Gross alpha and gross beta radioactivity concentrations in sediment samples of the Gulf of Izmir are given in Table 3. The activity concentrations of the gross alpha and beta values are ranged from 0.49 to $1.6 \mathrm{~Bq} \mathrm{~kg}^{-1}$ with a mean of $0.77 \mathrm{~Bq} \mathrm{~kg}^{-1}$ and 3.05 to $5.20 \mathrm{~Bq} \mathrm{~kg}^{-1}$ with a mean of $3.66 \mathrm{~Bq} \mathrm{~kg}^{-1}$, respectively.

According to Table 3, the gross beta activity is higher than the corresponding gross alpha activity concentrations at all locations. K-40 isotope in molten state potassium results in high radioactivity in seawater. Thorium isotope's solubility is low in seawater, so gross alpha activity comes from uranium and radium radionuclides (15). 
Table 2:The vertical distribution of the drilling samples (13).

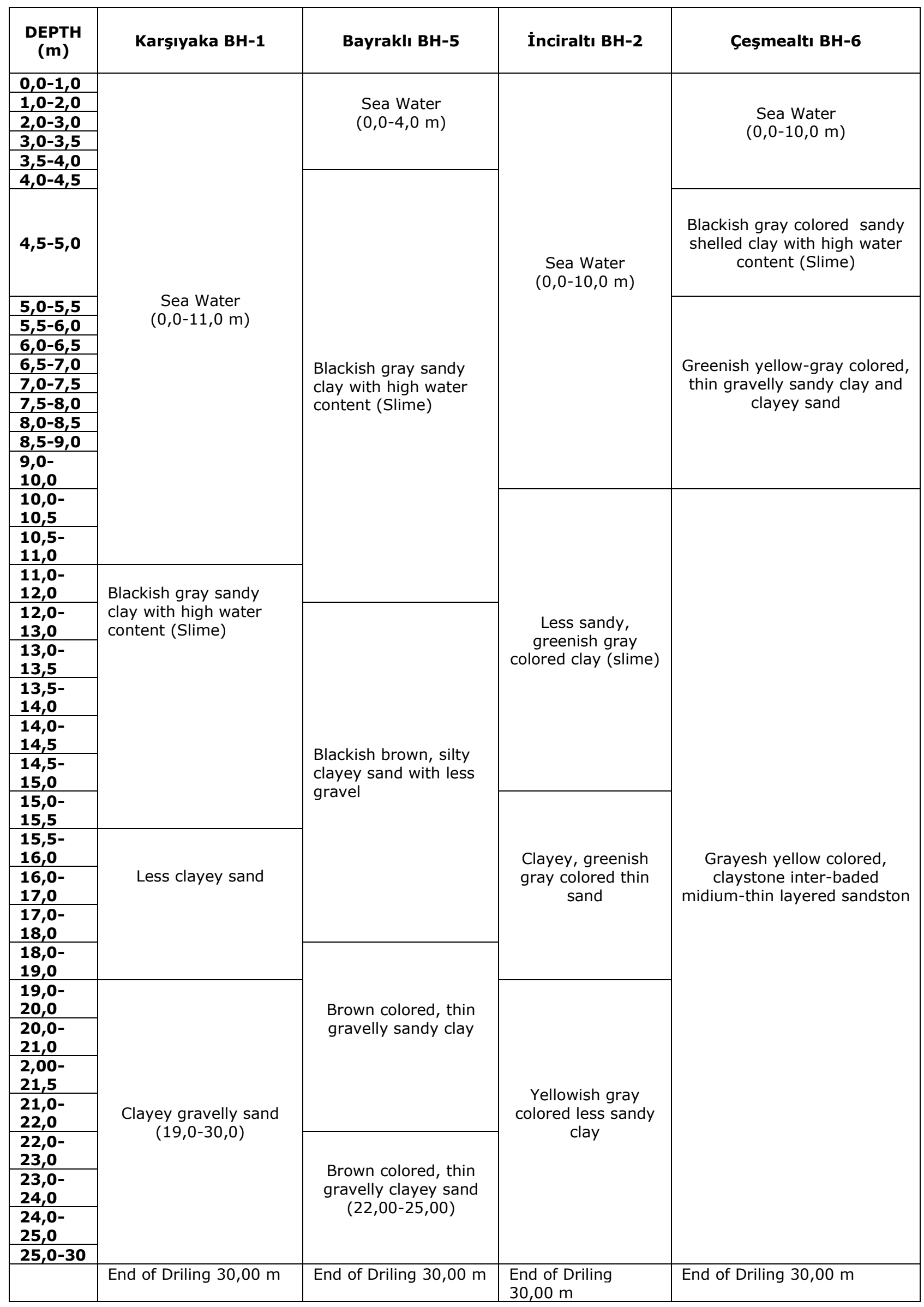


There is no regulatory standard for radiological contaminants in gross alpha and gross beta activity concentrations in sediments for comparing obtained data. Table 4 shows a comparison of results with various studies.

The results showed that gross alpha and gross beta activity concentrations in sediment samples were relatively higher than the majority of the other works. The differences can be explained by geological features of the sea and the content of mineral substances. The gross alpha activity concentrations in sediments are illustrated as the entire radioactivity of all alpha emitters that is mainly coming from the uranium and radium isotopes. Natural radionuclides are found mostly in high concentrations in volcanic, phosphate, granite, and salt rocks (16). Andesite-type volcanic rocks and their decomposition products are highly widespread around the Gulf of Izmir (17). $\mathrm{BH}-1, \mathrm{BH}-2$ and $\mathrm{BH}-5$ shows similar results than $\mathrm{BH}-6$ because Cesmealti (Urla) covers volcanic density stream sediments (18).

The highest concentrations of both gross alpha and gross beta were found at Cesmealti $\mathrm{BH}-6$ sampling site. It may be due to high amount of potassium entering the sea. Moreover, agricultural activities may cause greater beta activity as a result of the extensive usage of fertilizers $(2,4)$.

Table 3: The gross alpha and beta radioactivity concentrations in core sediments.

\begin{tabular}{ccc}
\hline Locations & Gross $\alpha(\mathbf{B q} / \mathbf{k g})$ & Gross $\beta$ (Bq/ kg) \\
\hline Karşıyaka BH-1 & $557 \pm 79$ & $1064 \pm 64$ \\
İnciraltı BH-2 & $592 \pm 77$ & $1238 \pm 85$ \\
Bayrakıı BH-5 & $537 \pm 77$ & $993 \pm 60$ \\
Çesmealtı BH-6 & $1800 \pm 207$ & $1842 \pm 102$ \\
\hline
\end{tabular}

Table 4: Comparison of the concentration range of radionuclides in sediments from different studies.

\begin{tabular}{llll}
\hline \multicolumn{1}{c}{ Stations } & Gross $\boldsymbol{\alpha} \mathbf{( B q} / \mathbf{k g})$ & Gross $\beta \mathbf{~ ( B q / k g ) ~}$ & References \\
\hline Gulf of Izmir & $537-1800$ & $993-1842$ & Present study \\
Maritza River, Turkey & $30-200$ & $6-1397$ & $(2)$ \\
Tundja River, Turkey & $30-158$ & $87-486$ & $(2)$ \\
Bosna River, Bosnia & $215-610$ & $495-628$ & $(4)$ \\
Bendimahi River, Turkey (in May) & $782-4596$ & $482-10372$ & $(19)$ \\
Bendimahi River, Turkey (in August) & $580-5824$ & $303-9702$ & $(19)$ \\
\hline
\end{tabular}




\section{CONCLUSION}

The main goal of this study was to obtain the background information about natural radioactivity in the intensive areas for the Gulf of Izmir by determining gross alpha and gross beta activity concentrations in sediment samples. The results indicated relatively high concentrations in the sediments that might be geological formation, mineral content and agricultural activities heavily affected the occurrence of natural radioactivity. The number of analyzing samples has to be done more, and the radiological levels and chemical parameters must be determined in air and water in the Gulf of Izmir to obtain a statistical conclusion.

\section{REFERENCES}

1. Cember $\mathrm{H}$, Johnson $\mathrm{T}$. Introduction to Health Physics. In: 4th ed. United States: McGraw-Hill; 1976.

2. Aytas S, Yusan S, Aslani MA, Karali T, Turkozu DA, Gok C, et al. Natural radioactivity of riverbank sediments of the Maritza and Tundja Rivers in Turkey. Journal of Environmental Science and Health, Part A. 2012;47(13):2163-2172.

3. Str \a alberg E, Varskog A, Raaum A, Varskog P. Naturally occurring radionuclides in the marine environment-an overview of current knowledge with emphasis on the North Sea area, Norse Decom. ND/E-19/03; 2003.

4. Wallova G, Kulichova Z, Rajczykova E, Makovinska J. Survey of radioactivity along the Bosna River. Journal of Radioanalytical and Nuclear Chemistry. 2016;307(1):247-252.

5. Noureddine A, Benkrid M, Hammadi A, Boudjenoun R, Menacer $M$, Khaber A, et al. Radioactivity distribution in surface and core sediment of the central part of the Algerian Coast: an estimation of the recent sedimentation rate. Mediterranean Marine Science. 2003;4(2):5358.

6. Bunzl K, Kracke W. Cumulative deposition of cesium-137, plutonium-238, plutonium-239, plutonium-240 and americium-241 from global fallout in soils from forest, grassland and arable land in Bavaria, West Germany. J Environ Radioact. 1988;8:1-14.

7. Corbacho J, Zapata-García D, Montaña M, Fons J, Camacho A, Guillén J, et al. Selection of the appropriate radionuclide source for the efficiency calibration in methods of determining gross alpha activity in water. Journal of environmental radioactivity. 2016;151:22-27.

8. Atgin RS, El-Agha O, Zararsız A, Kocataş A, Parlak H, Tuncel G. Investigation of the sediment pollution in Izmir Bay: trace elements. Spectrochimica Acta Part B: Atomic Spectroscopy. $2000 ; 55(7): 1151-1164$.

9. Bergin F, Kucuksezgin F, Uluturhan E, Barut I, Meric E, Avsar N, et al. The response of benthic foraminifera and ostracoda to heavy metal pollution in Gulf of Izmir (Eastern Aegean Sea). Estuarine, Coastal and Shelf Science. 2006;66(3):368-386.

10. Atalar M. İzmir Körfezi'nin sedimantolojik, mineralojik ve jeofizik etüdü. In İzmir: Dokuz Eylül Üniversitesi; 2013.

11. Yümün ZÜ, Meriç E, Avşar N, Nazik A, Barut İF, Yokeş B, et al. Meiofauna, microflora and geochemical properties of the late quaternary (Holocene) core sediments in the Gulf of Izmir (Eastern Aegean Sea, Turkey). Journal of African Earth Sciences. 2016;124:383-408. 
12. Eryılmaz M, Aydın Ş, Türker A. Ege Denizi'nin güncel çökel dağılım haritası. In: 55 Turkey Geological Congress, Abstracts Book Room Chamber of Geological Engineers. Ankara: Jeoloji Mühendisleri Odası;

13. Kurt D, Yümün Z, Barut I, Kam E. Distribution of Gamma Radiation Levels in Core Sediment Samples in Gulf of Izmir: Eastern Aegean Sea, Turkey. World Academy of Science, Engineering and Technology, International Journal of Environmental, Chemical, Ecological, Geological and Geophysical Engineering. 2016;10(3):392-396.

14. Karahan G, Öztürk N, Bayülken A. Natural radioactivity in various surface waters in Istanbul, Turkey. Water Research. 2000;34(18):4367-4370.

15. Otansev $P$, Taşkın $H$, Başsarı A, Varinlioğlu A. Distribution and environmental impacts of heavy metals and radioactivity in sediment and seawater samples of the Marmara Sea. Chemosphere. 2016;154:266-275.

16. Kumru M, Aydın B, Bakaç M. Gediz Nehri'nden Ege Denizi'ne Taşınan Doğal Radyoaktivitenin (Radyum) Belirlenmesi. Ekoloji Çevre Dergisi. 2002;10(43):22-25.

17. Koca M. Formation features and engineering properties of the clays produced from the weathering of the andesites in Izmir and vicinity. Geol Bull Turk. 1999;42(2).

18. GÖKTAŞ F. İZMİR-DIŞ-KÖRFEZİNDEKİ ADALARIN NEOJEN STRATIGGRAFISİ. Maden Tetkik ve Arama Dergisi. 2016;152(152).

19. Zorer ÖS, Ceylan H, Doğru M. Gross alpha and beta radioactivity concentration in water, soil and sediment of the Bendimahi River and Van Lake (Turkey). Environmental monitoring and assessment. 2009;148(1-4):39-46. 
